UNITED STATES DEPARTMENT. OF THE INTERIOR

Harold L. Ickes, Secretary

GEOLOGICAL SURVEY

W. C. Mendenhall, Director

Bulletin 931-0

\title{
NICKEL DEPOSIT NEAR GOLD HILL BOULDER COUNTY, COLORADO
}

BY

E. N. GODDARD AND T. S. LOVERING

Strategle Minera ts Investigations, 1941

(Pages 349-362)

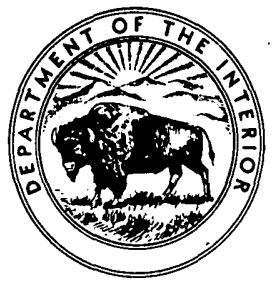

UNITED STATES

GOVERNMENT PRINTING OFFICE WASHINGTON : 1942

For walo by the Superintendent of Documente, Washington, D. C. - . + . - - Price 30 cento 



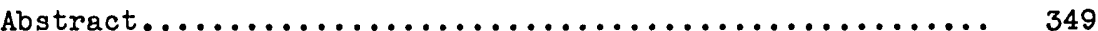

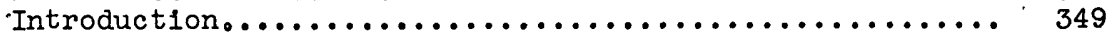

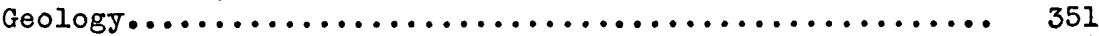

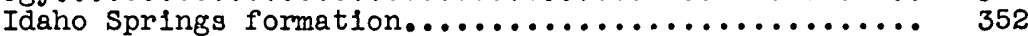

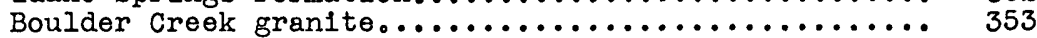

Hornblende-quartz gabbro................... 354

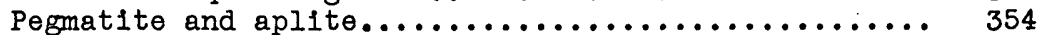

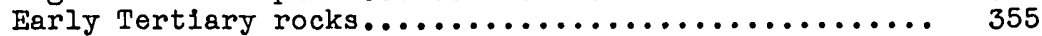

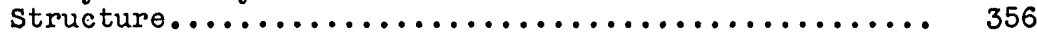

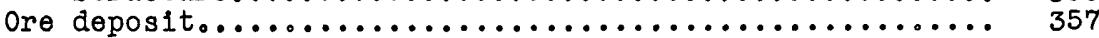

Occurrence and character of the ore................. 357

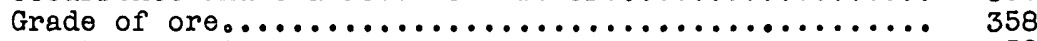

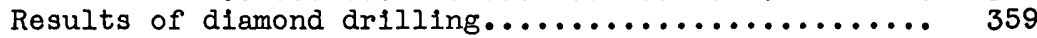

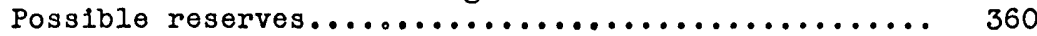

Age and origin of the nickel ore.................. 361

\section{ILLUSTRATIONS}

Page

Plate 59. Generalized geologic map of the vicinity of Gold Hill, Colorado, showing the regional setting of the Copper King nickel deposit... 352 60. Geologic maps and sections of the Copper King mine, Boulder County, Colorado..... In pocket Figure 37. Index map of Colorado showing the location of the Copper King nickel deposit......... 350 

NICKEL DEPOSIT NEAR GOLD HILL,

BOULDER COUNTY, COLORADO

$\circ$

By E. N. Goddard and T. S. Lovering

\section{ABSTRACT}

The nickel deposit of the Copper King mine, near Gold Hill, 32 miles northwest of Denver, Colo., is in the pre-Cambrian rocks of the Colorado Front Range. The deposit is in a lenticular layer of amphibolite in blotite schist of the Idaho Springs formation, half a mile west of the border of a small batholith of the pre-Cambrian Boulder Creek granite. A dikelike body of hornblende-quartz gabbro, related to the granite, is exposed in the lower workings, and many irregular pegmatite dikes cut the schist, amphibolite, and gabbro.

Disseminated intergrowths of pyrite, pyrrhotite, chalcopyrite, and several nickel minerals have replaced hornblende in the coarser-grained and more calcic beds of the amphibolite layer. Numerous samples of the sulfide ore taken by the Cobalt Gold Mining Co. yielded from 0.48 to 6 percent nickel, 0 to 0.60 percent cobalt, and small percentages of copper. Samples of oxldized ore contained from 1.32 to 13.02 percent nickel, 0.22 to 6.22 percent cobalt, and 0.05 to 31.60 percent copper. On the basis of development work and diamond drilling, there seems to be about 25,000 tons of ore blocked out that contains between 2 and 3 percent nickel and an additional 30,000 tons of ore that will average about 0.5 percent nickel.

The deposit seems to be comparatively small, but the orebearing beds are so dislocated by the gabbro and by pegmatite dikes that it is impossible to project their extensions far beyond the mine workings. The ore appears to be genetically related to the pre-Cambrian gabbro dike. There are several copper deposits of this general type in other parts of the Front Range, but the only other known nickel-bearing deposit lies about 120 miles to the south.

\section{INTRODUCTION}

Scattered throughout the Colorado Front Range, there are many. small copper deposits, believed to be of pre-Cambrian age. I] They have been widely prospected but have produced little or. no

1/ Boyd, James, Pre-Cambrian ore deposits of Colorado: Unoublished doctor's thesis at the Colorado School of Mines, 1934. 
ore. In one of these, the Copper King mine, near Gold H1ll, Colo., nickel was discovered in 1930, and development in the following years has exposed some 25,000 tons of ore containing from 2 to 3 percent of nickel. No other nickel deposit is known In the Front Range, but a somewhat similar deposit has been

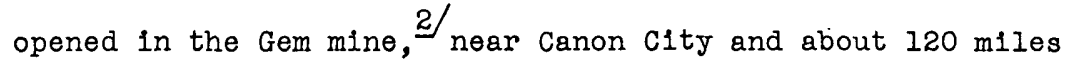
south of Gold Hill.

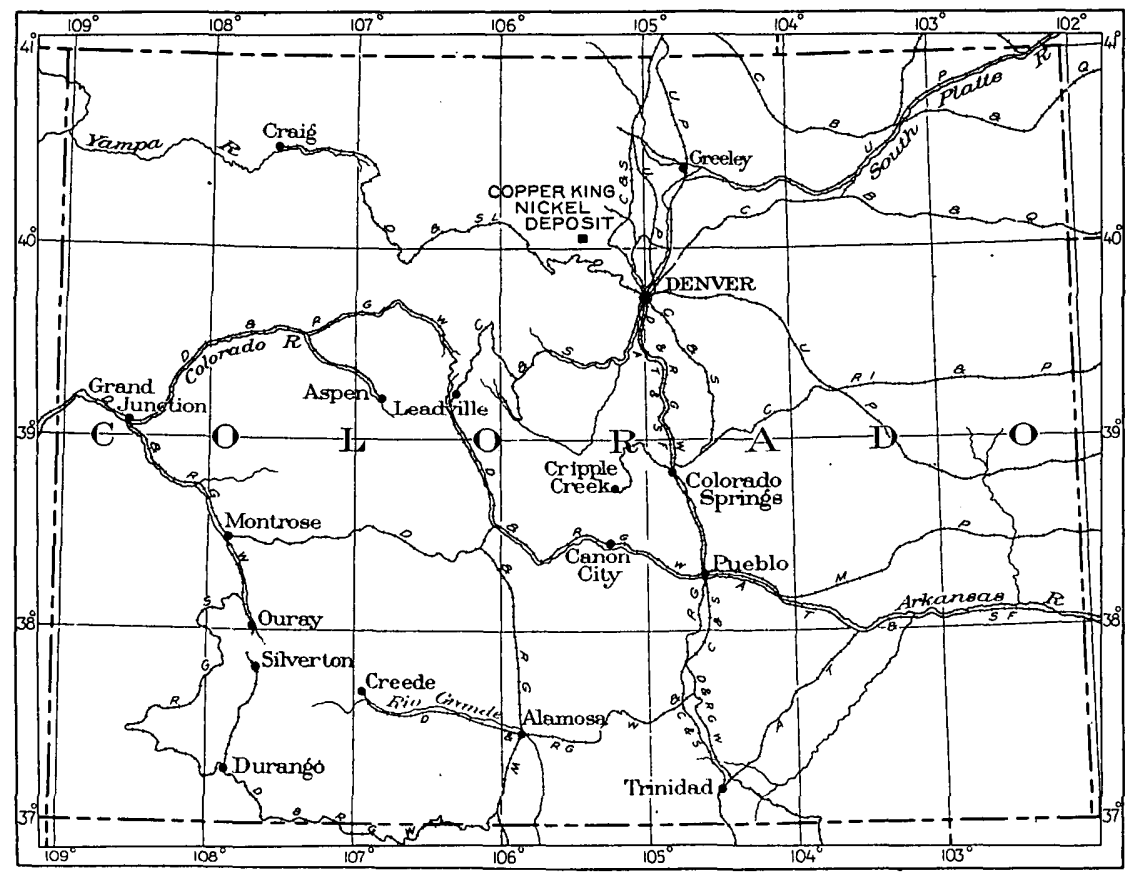

$25 \quad 25 \quad$ so $25 \quad$ T5 MiLES

Plgure 37.-Index map of Colorado showling the location of the Copper King nickel deposit.

The Copper King mine, owned by the Cobalt Gold Mining Co., is near the top of a high ridge in the Front Range foothills at an altitude of about 8,350 feet. It is three-quarters of a mile southwest of Gold Hill and 32 miles northwest of Denver (fig. 37). The mine is on the western edge of the Gold Hill mining district, $3 /$ in which there are numerous gold-telluride and sil-

2) Chariton. Thomas, Discussion of paper by Philip Argall on Nickel; the occurrence, geological distribution and genesis of 1ts ore deposits: Colorado Sc1. Soc. Proc., vol. 4, pp. 420-421, 1893.

3/ Goddard, E. N., Prellminary report on the Gold Hill mining district, Boulder County, Colo.: Colorado Sc1. Soc. Proc., vol. 14, no. 4, pp. 103139. 1940. 
ver-lead veins of early Tertiary age. The chlef mine workings are two tunnels which aggregate about 1,600 feet. These are 110 feet apart vertically, and are connected by a winze. The upper tunnel is connected by a shaft with an open cut on the surface. The writers first visited the Copper King mine in the summer of 1935 and spent a day studying the structure in the underground workings. In the summer of 1937, Goddard spent 4 days mapping the geology of the underground workings in deta1l. In 1939, he made a brief visit to study diamond-drill cores and to map some of the surface geology, and in 1940 another to map new workings. Lovering studied polished specimens of the ore under the microscope and identified the nickel minerals.

The writers gratefully acknowledge the cooperation of Ward Yeager, manager of the company, and J. H. Rodgers, mining eng1neer, who furnished maps, assay figures; and other helpful information. They are also indebted to Miss Jewell Glass of the Geological Survey for help in identifying several minerals, and to F. C. Calkins and H. G. Ferguson for suggestions during, the preparation of this report.

\section{GEOLOGY}

The regional geology is depicted on plate 59. The nickel deposit is in an area of schists and gneisses of the Idaho Springs formation, about half a mile from the border of a small batholith of the pre-Cambrian Boulder Creek granite. The follation of the schists and gneisses has in general a northeasterly strike and a steep northwesterly dip. The chlef rock is a biotite schist, but in a few places there are lenticular layers of calcic amphibole gneiss, known locally as lime-silicate rock, that ranges in character from a coarse inequigranular aggregate of plagioclase and ferromagnesian minerals to a medium-grained amphiboilte. These layers are mostly from 10 to a few hundred feet thick. The gnelss was probably formed by the metamorphism 
of impure limestone and limy shale beds in an extensive shale formation. Amphibolite layers of this group contain the Copper King nickel deposit and other deposits of 1 ts type.

The local geology at the Copper King mine is shown on the mine maps and sections of plate 60. The surface in this vicinity is so covered with float that few contacts could be traced accurately. Amphibolite of the Idaho Springs formation crops out over an area about 500 feet long and 200 feet wide. It is bordered on the north and west by blotite schist and is cut off on the south side by a large mass of pegmatite. This amphibolite is cut by several kinds of rocks, the earliest of which are small dikes of Boulder Creek granite. A small dikelike mass of hornblende-quartz gabbro, exposed in the lower workings, has thrust aside the amphibolite layers so that they tend to wrap around it. Numerous irregular pegmatite and aplite dikes related to the Boulder Creek granite cut all the other pre-Cambrian rocks. These pre-Cambrian rocks are cut by segments of $a$. long diabase dike called the Iron dike, and by stocks and dikes of various early Tertiary igneous rocks that are common in the region.

\section{Idaho Springs formation}

The biotite schist, which makes up most of the Idaho Springs formation, is a medium-grained, strongly follated, dark-gray to black rock containing variable amounts of blotite, quartz, relaspar, and muscovite. In places sillimanite is also present. Locally the schist grades into an injection gneiss in which the follation is less pronounced and biotite less abundant.

The amphibolite is made up chiefly of hornblende, although blotite and bytownite are locally abundant. The rock is fine to moderately coarse-grained and very uneven in texture, and it shows a faint gneissic structure parallel to the bedding. 

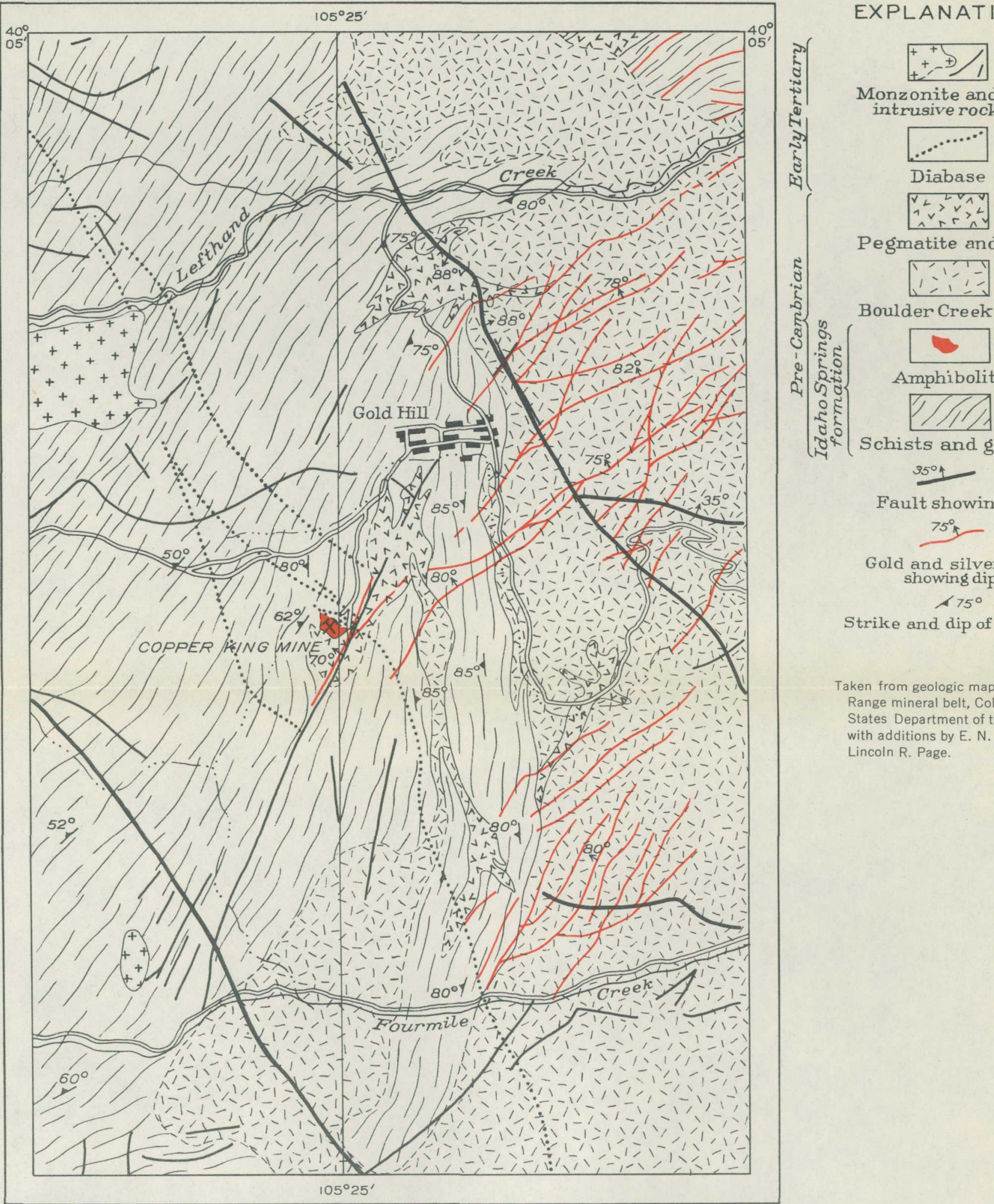

Monzonite and other intrusive rocks

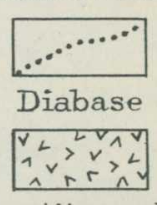

Pegmatite and aplite

Boulder Creek granite

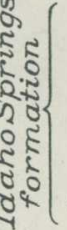

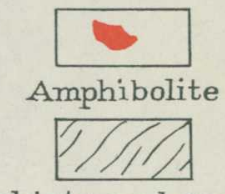

Schists and gneiss

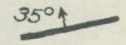

Fault showing dip $75^{\circ} \mathrm{i}$

Gold and silver vein showing dip $175^{\circ}$

Strike and dip of foliation

Taken from geologic map of the Front Range mineral belt, Colorado, United States Department of the Interior, with additions by E. N. Goddard and Lincoln R. Page.

GENERALIZED GEOLOGIC MAP OF THE VICINITY OF GOLD HILL, COLORADO, SHOWING THE REGIONAL SETTING OF THE COPPER KING NICKEL DEPOSIT 
Two varieties of hornblende are common in the amphibolite. Pargas1te, the common dark-green hornblende, occurs in broad stubby moderately coarse crystals. The other varlety, probably edenite but possibly hastingsite, is grayish green to brown and occurs in smaller, more acicular crystals that form a meshlike intergrowth. Some layers of the amphibolite are composed mostly of pargasite, in others edenite (?) predominates, and in still others biotite is the chief mineral. Bytownite is nearly absent in some layers but is abundant in others.

In the southeastern part of the lower tunnel, where the two curved drifts nearly come together, there is a facies of the amphibolite that closely resembles the gabbro in appearance. It Is dark greenlsh gray and has a medium, relatively even texture and very faint gneissic structure. It is made up of hypersthene, labradorite, hornblende (hastingsite-pargasite), and blotite, and thus has the composition of a norite. The writers had ne1ther time nor material for a thorough study of this very interesting rock, but it seems to have been a result of reaction be- . tween the amphibolite and fluids from the gabbro.

\section{Boulder Creek granite}

The Boulder Creek granite in the small batholith to the east of the Copper King mine is a slightly gneissic rock of variable composition and texture. In the north-central part of the batholith it is a coarse-grained granite made up of large pink microcline phenocrysts in a coarse matrix of quartz, oligoclase, and blotite. Near the borders and in the southern part the rock is medium-grained, distinctly gneissic, and grades from granite to quartz monzonite in composition. The irregular dikes in the Copper King mine are medium-grained and show a slight alinement of the mineral grains parallel to the dike.

$4341110-42-2$ 


\section{Hornblende-quartz gabbro 4}

Hornblende-quartz gabbro forms a large dike which is exposed in the lower tunnel level but does not reach the surface. Its shape could not be easily determined from the exposure in the tunnel, but diamond drilling has served to delineate the mass fairly well. It is probably a dike, 60-75 feet wide, which strikes N. $30^{\circ}-60^{\circ} \mathrm{W}$. and $\operatorname{dips} 50^{\circ}-70^{\circ} \mathrm{NE}$. At the southeastern end of the lower level, numerous irregular fingers branch from the dike ani intrude the amphibolite subparallel to the bedding (see drill hole 3, pl. 60). The top of the dike, whose cross section is shown on plate 60, appears to plunge to the northeast at a moderate angle.

In the Copper King mine this gabbro is a medium-grained, dark-speckled, gray to greenish-gray rock made up of about 40 percent hornblende, 40 percent bytownite (about $\mathrm{An}_{80}$ ), 10 percent biotite, 5-6 percent quartz, 4-5 percent 1lmenite, and small quantities of pyrite, pyrrhotite, and apatite. In places It appears to grade into the amphibolite, and there the contact of the two rocks is not easily found. The gabbro tends to become finer-grained along its borders.

This dike appears to belong to a group of hornblendic dike rocks that are common in and near masses of Boulder Creek gran- 1te and are believed to be genetically related to 1 t.

\section{Pegmatite and aplite}

Numerous pegmatite dikes cut the pre-Cambrian rocks in the vicinity of the mine. The commonest type is a coarse-grained biotite pegmatite, dikes of which cut the gabbro and adjacent rocks and are commonly bordered by a zone of biotite where they cut the amphibolite. Nearly pure medium-grained biotite forms

4/ This rock was called diorite in a previously published abstract (Econ. Geoloey, vol. 34, p. 131, 1939), but mlcroscopic work has shom it to be a gabbro. 
a selvage a few inches to 18 inches wide along the borders of many of the pegmatite dikes, or occurs as segregations near. their borders. Other pegmatites, which contain a little muscovite but little or no blotite, grade into aplite. They do not cut the gabbro dike and may be earlier.

\section{Early Tertlary rocks}

As shown on plates 59 and 60 , a dabase dike of northwesterIf trend is exposed on the surface and in the lower tunnel. This dike can be traced for about 40 miles diagonally across the Front Range, and 1t therefore may be expected to persist to considerable depth. Its age has been shown by its relations elsewhere to be Paleocene. It is a black, medium- to fine-grained rock with a diabasic texture which is indistinct except on weathered surfaces. Angular blocks of float from this dike spread over much of the hillside in the vicinity of the mine.

In the area shown on plate 59, there are two stocks and many dikes of monzonite and related rocks that are younger than the diabase and are belleved to be of early Tertlary age. One of these dikes, a blotite monzonite, is cut in drill hole no. 3, at a point 375 feet southeast of the lower tunnel workings. These early Tertiary igneous rocks apparently have no relation to the ore deposit at the Copper King mine, though they are genetically related to the numerous veins of gold-telluride and pyritic gold-silver ores in the Gold Hill district. Many of these veins are shown in the eastern part of plate 59. Two of the veins containing pyritic gold-silver ore are cut in drill hole no. 3 (see pl. 60) and are explored in the Seven-Thirty mine, 500 feet southeast of the Copper King.

5/ For a description of these rocks and their relationships, see LoverIng, T. S., and Goddard, E. N., Laramide lgneous sequence and differentiation in the Front Range, Colo.: Geol. Soc. Amertca Bull., vol. 49, pp. 35$68,1938$. 


\section{Structure}

The regional trend of the follation in the Idaho Springs formation is northeastward, and the dip ranges from nearly vertical to $50^{\circ} \mathrm{NW}$. (See pl. 59.) In the vicinity of the Copper King mine, the regional trend has been somewhat distorted by intrusions of the gabbro and of the pegmatite dikes. In the mine workings, as shown on plate 60 , the follation of the amphibolite and bordering schist has a general northwest trend; the dip changes from $37^{\circ}-60^{\circ} \mathrm{W}$. near the portals of the tunnels to $60^{\circ}-70^{\circ} \mathrm{NE}$. In the southeastern part of the workings. This reversal of dip suggests that the amphibolite layers lie in a nearly isoclinal anticline, but the results of recent diamond drilling and drifting do not substantiate this idea, and it therefore seems probable that the beds form a steeply dipping homocline with local contortions and irregularities caused by folding and intrusions (see sections on pl. 60).

Faults are numerous in the Copper King mine, but none appear to have a large displacement. A low-angle fault exposed in the lower level of the mine strikes N. $58^{\circ}-72^{\circ} \mathrm{W}$, dips $35^{\circ}-42^{\circ} \mathrm{NE}$. and cuts across the roof of the gabbro dike. As nearly as can be determined, the net displacement has been about 18 inches, and the hanging wall has moved down and to the northwest at an angle of about $30^{\circ}$. There may, however, have been more than one period and direction of movement. The fault zone contains 12 to 18 inches of sheared rock, and in places it contains an inch or less of quartz and nickel ore. The fault is cut off by the Paleocene diabase dike, but small slips continue into the dike. The main fault may be of pre-Cambrian age.

Many other small faults and slips are found in the workings, and evidence of movement along the walls of pegmatite dikes is common, but none of the minor faults appears to have a displacement of more than a few feet and none can be traced on the sur- 
face. Several thin gouge seams and a few shear zones ranging up to 4 feet in width have been cut in the diamond-drill cores, but information is lacising as to strike, dip, and displacement along the faults that they follow.

ORE DEPOSIT

\section{Occurrence and character'of the ore}

The nickel ore occurs in the coarser-grained and more calcic layers of the amphibolite. These ore-bearing layers are commonIy from 5 to 20 feet in maximum thickness, but in the lower tunnel level there is a zone from 40 to 50 feet wide that contains a small percentage of nickel. In these layers, pyrrhotite, pyrite, chalcopyrite, and several nickel minerals are irregularIy disseminated or form a network and replace various minerals of the amphibolite. Their localization in certain layers seems to be dependent on three factors: The composition of the layers, their texture, and the presence of minor shearing and fracturing, which is only evident under the microscope. The sulfide minerals have chiefly replaced both varieties of hornblende in the coarser-grained facies, but in places they have extensively replaced bytownite and rarely biotite. In the hypersthene-labradorite facies, the sulfide minerals have replaced both hypersthene and hornblende.

A microscopic study of the ore shows the following sulfide minerals to be present, listed in the order of their probable age beginning with the oldest:

1. Pyrite and arsenopyrite.

2. Pyrite and polydymite $\left(\mathrm{N}_{3} \mathrm{~S}_{4}\right)$.

3. Pyrrhotite。

4. Sphalerite, chalcopyrite, and quartz.

5. Bravoite ( $\left.(\mathrm{Fe}, \mathrm{N} 1) \mathrm{S}_{2}\right)$.

6. Vlolarite $\left((\mathrm{N1}, \mathrm{Fe}) \mathrm{S}_{4}\right)$ 。

7. Pyrite, cobaltite (CoAsS), niccolite (NiAs), pentlandite (NiFes), and millerite'?) (N1S).

The early pyrite is euhedral to subhedral and moderately coarse, and in places it contains zones of arsenopyrite. 
Abundant polydymite and a second generation of pyrite, intimately associated, replace hornblende and commonly have a pecullar laminated structure. This combination is replaced by pyrrhotite, the most abundant sulfide mineral. Sphalerite, chalcopyrite, and quartz were formed, in small quantity, slightly later than the pyrrhotite. In ore from the lower level, bravoite replaces and veins the earlier minerals and is intimately associated in places with violarite but seems to be slight]y earlier. A very little niccolite and pyrite are also associated with the bravoite but seem to be later. Ore from above the lower level is complexly veined with violarite, which in turn is cut by tiny veinlets of pyrite, cobaltite, and pentlandite (?). Millerite (?) forms feathery fringes to the violarite veinlets and numerous tiny veinlets in most of the polydymite.

The polydymite seems to be the chief primary nickel mineral present in the ore. The mode of occurrence of the others suggests that they may be of supergene origin.

In completely oxidized ore the chief constituents appear to be garnierite, chrysocolla, and serpentine. Complete oxidation extends to a depth of 15-20 feet below the surface, and partial oxidation to a depth of about 50 feet. Other supergene effects, that is, the replacement of the earlier sulfides by later nickel minerals, apparently extend below the lower level.

\section{Grade of ore}

The grade of the ore shows great variation ovon in individual layers. Sulflae ore that sooms to bo chiefly primary contains from 0.48 to 6 percent nickel, from 0 to 0.60 percent cobalt, and a small amount of copper, according to assays furnished by the Cobalt Gold Mining Co. Some of this ore, however, may have undergore'supergene enrichment. Samples of the oxidized ore, taken from within 50 feet of the surface, assayed 
from 1.32 to 13.02 percent nickel, from 0.22 to 6.22 percent cobalt, and from 0.05 to 31.60 percent copper.

The most consistent group of assays were from samples of sulfide ore exposed in new development work in the southeastern part of the upper tunnel. Here six samples taken over a length of 55 feet and widths of $3 \frac{1}{2}-11$ feet assayed from 2.91 to 5.66 percent nickel, 0.32 to 1.15 percent copper, and 0.13 to 0.21 percent cobalt. In the winze between tunnel levels, four samples taken 15 to 35 feet apart over widths of $2 \frac{1}{2}-10$ feet contained from 3.00 to 5.28 percent nickel and from 0.34 to 0.54 percent copper.

For samples from the lower tunnel, assay results have been less consistent. In an ore-bearing layer on the northeast side of the diabase dike, the nickel content ranged from less than 1 percent to 3 percent at most, whereas the samples taken from a similar layer on the south side of the dike contained from 3 to 6 percent nickel. Relatively recent development work in the southeastern part of the lower tunnel has exposed a zone from 40 to 50 feet wide in which the rock averages $0.41-0.62$ percent nickel, but the ore-bearing bed is cut by irregular barren tongues of gabbro.

\section{Results of diamond drilling}

In 1939 the company carried on a diamond-drill exploration program in which 16 holes totaling 2,520 feet were drilled from the lower level. These explored the ground to a depth of 152 feet below the lower tunnel level and gave much valuable information about the ore and the structure. Ore was cut in various places from the lower tunnel to a depth of 115 feet below 1t, and samples assayed as high as 5.30-percent nickel. Although the shape of the hornblende-quartz gabbro dike and the downward extension of the diabase dike were satisfactorily determined, the structure of the amphibolite and pegmatites is apparently 
too complex to be deciphered without more drilling. No tonnage estimates could be made from the available data. As shown on plate 60 , the gabbro dike apparently dips northeastward at $50^{\circ}$ $70^{\circ}$ and cuts off the ore that is exposed in the tunnel level and diamond-drill holes. Unfortunately, only one diamond-drill hole (no. 12) penetrated to the lower, or footwall side of the gabbro dike, and its direction is approximately parallel to the follation of the amphibolite (see plate 60, map of lower level). This hole reached the amphibolite about 100 feet southeast of the present workings and entered another gabbro body in the last 25 feet. No minable ore was penetrated by the hole, but occasional spots of sulfide were found in the core and indicate the presence of sulfide mineralization beneath the dike. In hole 15 (see section C-C' on pl. 60), a mass of amphibolite containing rather abundant disseminated sulfides was encountered near the lower side of the dike, but this appeared to be an inclusion, for the drill again penetrated gabbro below it.

The drill cores suggest that the wide zone of ore containing 0.41-0.62 percent nickel in the southeastern part of the lower tunnel is actually made up of a group of narrow ore zones assayIng 1 percent or better, separated by barren zones, as shown in hole 3. In the tunnel workings, however, these zones could not be separately identified.

\section{Possible reserves}

It is exceedingly difficult to estimate the reserves in this deposit because of the irregular distribution of the sulfides in the ore-bearing layers and because of the dismuption of these layers by later rocks. The mass of amphibolite may enlarge downward or may be largely obliterated by the gabbro and pegmatite intrusions. Moreover, as already pointed out, it is not known whether ore is present at depth on the footwall side of the gabbro dike or not. However, the assay records of the com- 
pany, which are believed to be rellable, seem to indicate that about 25,000 tons of ore that contain between 2 and 3 percent of nickel has been blocked out by drifting. The openings in the lower tunnel together with the diamond drilling have blocked out about 30,000 tons of additional ore which w1ll average about 0.5 percent nickel in a zone 40-50 feet thick; if this zone is made up of a group of narrow layers that can be mined selectively, this latter figure may be changed to 15,000 tons that will average 1 percent nickel. Apart from this, there is probably no great tonnage of ore on the northeast side or hanging wall of the gabbro dike, and there is no way of predicting what lies on the footwall side except by sinking a shaft or by further diamond drilling. If the amphibolite persists far downward, there is a possibility that a considerable tonnage of ore lies below.

\section{Age and origin of the nickel ore}

The Copper King nickel deposit is thought to be of pre-Combrian age. It is apparently older than the diabase dike, which is one of the earliest igneous rocks of the region intruded after pre-Cambrian time and is earlier than the ores of early Tertlary age. $6 /$ The hornblende-quartz gabbro dike contains small amounts of disseminated pyrite, pyrrhotite, and chalcopyrite, which appear to be primary constituents. It therefore seems probable that the nickel ore is genetically related to the gabbro, and the pre-Cambrian age of the group to which this rock belongs is fairly well established in other parts of the Front Range.

of the various other sulfide deposits of this type scattered throughout the Front Range, only one, the Gem mine $7 /$ about 120 miles to the south, has been found to contain apprecieble amounts of nickel. Most of these deposits, like the Copper King,

6/ Lovering, T. S., and Goddard, R. N., op. c1t., p. 43.

I Charlton, Thomas, op. c1t., pp. 420-421. 
were explored for copper and gold in the early days, when little attention was paid to nickel, and it is possible that a careful survey of other deposits might reveal nickel contents comparable to that of the copper King mine.

O 
The use of the subjoined mailing label to return this report will be official business, and no postage stamps will be required

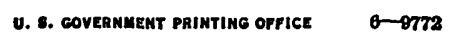

\section{UNITED STATES \\ DEPARTMENT OF THE INTERIOR \\ GEOLOGICAL SURVEY \\ OFFICIAL BUSINESS \\ This label can be used only for returning official publications. The addrees mute not} be changed.

\section{PENALTY FOR PRIVATE USE TO AVOID} PAYMENT OF POSTAGE, $\$ 300$

\section{GEOLOGICAL SURVEY,}

